\section{A) Check for updates}

Cite this: Org. Chem. Front., 2017, 4, 565

Received 26th December 2016, Accepted 17th January 2017

DOI: $10.1039 / c 6 q 000854 b$

rsc.li/frontiers-organic

\title{
Silver-catalyzed radical carbofluorination of unactivated alkenes with acetic acid in aqueous solution $\uparrow$
}

\author{
He Chen, ${ }^{a}$ Lin Zhu ${ }^{a}$ and Chaozhong Li*a,b
}

The $\mathrm{AgNO}_{3}$-catalyzed reactions of unactivated alkenes with acetic acid and Selectfluor reagent in aqueous solution afforded the corresponding $\gamma$-fluorinated carboxylic acids under mild conditions. Carbofluorination was not only efficient and regioselective, but also enjoyed a wide functional group compatibility.

\section{Introduction}

Fluorinated molecules have found increasingly important roles in pharmaceuticals and agrochemicals. ${ }^{1}$ The introduction of fluorine atoms into pharmaceuticals can make them more lipophilic and metabolically stable, and increase the strength of their interactions with target proteins. ${ }^{1 a}$ As a consequence, significant efforts have been devoted to the development of new methods for $\mathrm{C}-\mathrm{F}$ bond formations under mild conditions in the past decade. ${ }^{2}$ In this aspect, $\gamma$-fluorinated aliphatic carboxylates are a class of compounds with important biological properties. ${ }^{3}$ They have also found applications as fluorinated probes in membrane topology and protein studies. ${ }^{4}$ In addition, they serve as useful building blocks for more complex molecules such as a fluorinated erythromycin antibiotic. ${ }^{5}$ However, these compounds required multistep syntheses, and the overall efficiencies were low. It is thus desirable to develop convenient and efficient methods for the synthesis of $\gamma$-fluorinated aliphatic carboxylic acids.

We recently reported the silver-catalyzed oxidative decarboxylative fluorination of aliphatic carboxylic acids with Selectfluor ${ }^{6}$ reagent (1-chloromethyl-4-fluorodiazoniabicyclo$[2,2,2]$ octane bis(tetrafluoroborate)) in aqueous solution. ${ }^{7}$ However, during our extension of this method, ${ }^{8}$ we observed that the decarboxylation of acetic acid was so sluggish that it could be used as a co-solvent in Selectfluor-mediated oxidative

\footnotetext{
${ }^{a}$ Key Laboratory of Organofluorine Chemistry and Collaborative Innovation Center of Chemistry for Life Sciences, Shanghai Institute of Organic Chemistry, Chinese Academy of Sciences, 345 Lingling Road, Shanghai 200032, China.

E-mail: clig@mail.sioc.ac.cn

${ }^{b}$ School of Chemical Engineering, Ningbo University of Technology, No. 89 Cuibai Road, Ningbo 315016, China

$\dagger$ Electronic supplementary information (ESI) available: Experimental details, characterization of products and copies of ${ }^{1} \mathrm{H},{ }^{13} \mathrm{C}$ and ${ }^{19} \mathrm{~F}$ NMR spectra. See DOI: $10.1039 / \mathrm{c} 6 q 000854 \mathrm{~b}$
}

radical fluorination reactions. ${ }^{8 b, d}$ Meanwhile, it is well documented that $\mathrm{Mn}(\mathrm{OAc})_{3}$-mediated oxidative radical addition of acetic acid to alkenes leads to $\gamma$-lactones. ${ }^{9}$ In light of these phenomena, we envisioned that acetic acid might be able to participate in the 1,2-carbofluorination of alkenes. It should be pointed out that only a few examples of intermolecular carbofluorination were reported and they mainly dealt with activated alkenes such as styrenes or enamines. ${ }^{8 d, 10}$ Herein we report the silver-catalyzed carbofluorination of unactivated alkenes by condensation with acetic acid and Selectfluor in aqueous solution, providing an efficient and general entry to various $\gamma$-fluorinated aliphatic carboxylic acids in one step.

\section{Results and discussion}

$N$-(Pent-4-en-1-yl)phthalimide (1a) was thus chosen as the model substrate for the optimization of reaction conditions (Table 1). In a preliminary test, alkene 1a was treated with Selectfluor (3 equiv.) and $\mathrm{AgNO}_{3}(20 \mathrm{~mol} \%$ ) in mixed solvents of $\mathrm{H}_{2} \mathrm{O}$ /dichloromethane(DCM)/AcOH at $50{ }^{\circ} \mathrm{C}$ for $24 \mathrm{~h}$, a condition similar to the carbofluorination of alkenes with $\beta$-ketoesters. ${ }^{8 d}$ Gratifyingly, the expected carbofluorination product 2a was obtained in 57\% yield (entry 1, Table 1). Both water and DCM were required as solvents, as evidenced by control experiments (entries 2 and 3, Table 1). Switching the catalyst $\mathrm{AgNO}_{3}$ to $\mathrm{AgBF}_{4}, \mathrm{AgPF}_{6}$ or AgOTf did not show any improvement (entries 4-6, Table 1). Next, several additives were screened in an attempt to increase the product yield. The addition of a base such as NaOAc inhibited the reaction (entry 7, Table 1). On the other hand, the addition of an acid such as trifluoroacetic acid (TFA) or nitric acid slightly increased the product yield (entries 8 and 9, Table 1). We then chose phosphoric acid as the co-solvent, and we were delighted to find that the carbofluorination product $2 \mathbf{a}$ was isolated in 
Table 1 Optimization of reaction conditions

\begin{tabular}{|c|c|c|c|c|}
\hline & NPhth $+\mathrm{CH}_{3} \mathrm{CO}_{2} \mathrm{H}$ & $\underset{\underset{50}{\circ} \mathrm{C}, 24 \mathrm{~h}}{\stackrel{\substack{\text { SelectFluor } \\
\mathrm{AgNO}_{3} \text { (cat) } \\
\text { additive }}}{\longrightarrow}}$ & \multicolumn{2}{|c|}{ NPhth } \\
\hline Entry $^{a}$ & Solvent & $50^{\circ} \mathrm{C}, 24 \mathrm{~h}$ & $\begin{array}{l}\text { Additive } \\
\text { (equiv.) }\end{array}$ & $\begin{array}{l}\text { Yield }^{b} \\
(\%)\end{array}$ \\
\hline 1 & \multicolumn{2}{|l|}{$\mathrm{H}_{2} \mathrm{O} / \mathrm{DCM} / \mathrm{AcOH}(1: 0.5: 0.5)$} & - & 57 \\
\hline 2 & \multicolumn{2}{|l|}{$\mathrm{H}_{2} \mathrm{O} / \mathrm{AcOH}(1: 1)$} & - & Trace \\
\hline 3 & \multicolumn{2}{|l|}{ DCM/AcOH $(1: 1)$} & - & Trace \\
\hline $4^{c}$ & \multicolumn{2}{|l|}{$\mathrm{H}_{2} \mathrm{O} / \mathrm{DCM} / \mathrm{AcOH}(1: 0.5: 0.5)$} & - & 56 \\
\hline $5^{d}$ & \multicolumn{2}{|l|}{$\mathrm{H}_{2} \mathrm{O} / \mathrm{DCM} / \mathrm{AcOH}(1: 0.5: 0.5)$} & - & 53 \\
\hline $6^{e}$ & \multicolumn{2}{|l|}{$\mathrm{H}_{2} \mathrm{O} / \mathrm{DCM} / \mathrm{AcOH}(1: 0.5: 0.5)$} & - & 47 \\
\hline 7 & \multicolumn{2}{|l|}{$\mathrm{H}_{2} \mathrm{O} / \mathrm{DCM} / \mathrm{AcOH}(1: 0.5: 0.5)$} & $\mathrm{NaOAc}(3)$ & 28 \\
\hline 8 & \multicolumn{2}{|l|}{$\mathrm{H}_{2} \mathrm{O} / \mathrm{DCM} / \mathrm{AcOH}(1: 0.5: 0.5)$} & TFA (3) & 58 \\
\hline 9 & \multicolumn{2}{|l|}{$\mathrm{H}_{2} \mathrm{O} / \mathrm{DCM} / \mathrm{AcOH}(1: 0.5: 0.5)$} & $\mathrm{HNO}_{3}(3)$ & 64 \\
\hline 10 & \multicolumn{2}{|c|}{$\mathrm{H}_{2} \mathrm{O} / \mathrm{DCM} / \mathrm{AcOH} / \mathrm{H}_{3} \mathrm{PO}_{4}(1: 0.5: 0.5: 0.6)$} & - & 82 \\
\hline 11 & \multicolumn{2}{|c|}{$\mathrm{H}_{2} \mathrm{O} / \mathrm{DCM} / \mathrm{AcOH} / \mathrm{H}_{3} \mathrm{PO}_{4}(1: 0.5: 0.5: 0.8)$} & - & 84 \\
\hline $12^{f}$ & \multicolumn{2}{|c|}{$\mathrm{H}_{2} \mathrm{O} / \mathrm{DCM} / \mathrm{H}_{3} \mathrm{PO}_{4}(1: 0.5: 0.8)$} & - & 17 \\
\hline $13^{g}$ & \multicolumn{2}{|c|}{$\mathrm{H}_{2} \mathrm{O} / \mathrm{DCM} / \mathrm{AcOH} / \mathrm{H}_{3} \mathrm{PO}_{4}(1: 0.5: 0.5: 0.8)$} & - & 0 \\
\hline \multicolumn{5}{|c|}{ 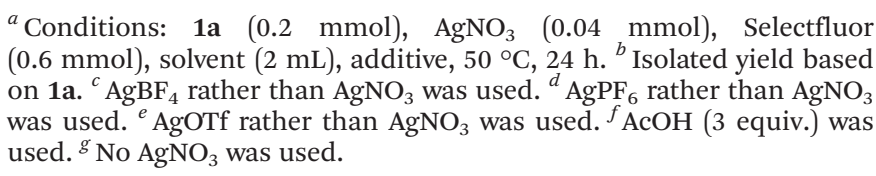 } \\
\hline
\end{tabular}

$84 \%$ yield (entry 11, Table 1 ). In the above cases, acetic acid was used as both the reagent and the co-solvent. Lowering the amount of $\mathrm{AcOH}$ to 3 equivalents significantly decreased the yield of 2a (entry 12, Table 1). Finally, the role of $\mathrm{AgNO}_{3}$ as a catalyst was proved by the control experiment (entry 13, Table 1).

With the optimized conditions (entry 11, Table 1) in hand, we set out to explore the scope and limitation of this method. The results are summarized in scheme 1 . The reactions of mono-substituted alkenes proceeded smoothly to afford the corresponding products $\mathbf{2 a - 2 i}$ in satisfactory yields. Disubstituted alkenes underwent efficient carbofluorination under slightly milder conditions (2 equivalents of Selectfluor and less $\mathrm{H}_{3} \mathrm{PO}_{4}$ ), leading to the synthesis of $\gamma$-fluorinated carboxylic acids $2 \mathbf{j}-\mathbf{2}$ p. A number of functional groups, including amide, tosylate, alkyl bromide or chloride, ester, nitrile, aryl and ketone, were well tolerated. All the reactions were carried out in aqueous solution and thus were very easy to operate. Nevertheless, the reaction was not applicable to activated alkenes such as styrene, in which a hydroxyfluorination product (2-fluoro-2-phenylethan-1-ol) was observed in about $40 \%$ yield. ${ }^{11}$ The extension of this method to propranoic acid or butanoic acid also failed because decarboxylative fluorination became competitive. These results clearly reveal the unique property of acetic acid from other alkanoic acids in silver-catalyzed radical fluorination reactions. ${ }^{7,8}$

The above results indicate that the reaction may proceed via a radical fluorination mechanism. To provide further evidence, 1,6diene 3 as a radical probe was prepared and subjected to the above optimized reaction conditions. Cyclopentane $\mathbf{4}$ was achieved in $38 \%$ yield as a mixture of two stereoisomers in an $83: 17$ ratio

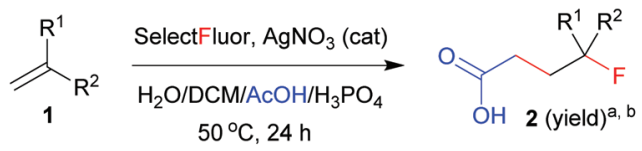<smiles>O=C(O)CCC(F)CCC[18OH]</smiles><smiles>O=C(O)CCC(F)CC[18OH]</smiles><smiles>O=C(O)CCC(F)CCCC[SeH3]</smiles><smiles>CCCC(F)CCC(=O)O</smiles><smiles>O=C(O)CCC(F)CCCBr</smiles><smiles>CCOC(=O)C(CC(F)CCC(=O)O)C(=O)OCC</smiles><smiles>O=C(O)CCC(F)COC(=O)c1ccccc1</smiles><smiles>N#CC(CC(F)CCC(=O)O)(c1ccccc1)c1ccccc1</smiles><smiles>O=C(O)CCC(F)CCCOC(=O)Br</smiles>

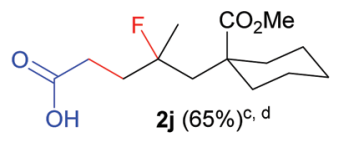<smiles>O=C(O)CCC(F)(CCCCl)CCCCl</smiles><smiles>CC(F)(CCOC(=O)Br)CCC(=O)O</smiles>

2I $\left(\mathrm{Ar}=p-\mathrm{CN}-\mathrm{C}_{6} \mathrm{H}_{4}, 87 \%\right)^{\mathrm{c}, \mathrm{d}}$ $2 \mathrm{~m}\left(\mathrm{Ar}=p-\mathrm{Ph}-\mathrm{C}_{6} \mathrm{H}_{4}, 50 \%\right)^{c}$ 2n $\left(\mathrm{Ar}=\mathrm{o}-\mathrm{CO}_{2} \mathrm{Me}-\mathrm{C}_{6} \mathrm{H}_{4}, 90 \%\right)^{\mathrm{c}, \mathrm{d}}$<smiles>CC(F)(CCOC(=O)CCC(=O)c1ccccc1)CCC(=O)O</smiles><smiles>CCOC(=O)C1(C(C)(F)CCC(=O)O)CCCC1</smiles>

Scheme 1 Carbofluorination of unactivated alkenes. ${ }^{a}$ Reaction conditions: 1 (0.2 mmol), Selectfluor $(0.6 \mathrm{mmol}), \mathrm{AgNO}_{3}(0.04 \mathrm{mmol}), \mathrm{DCM}$ $(0.5 \mathrm{~mL}), \mathrm{H}_{2} \mathrm{O}(1 \mathrm{~mL}), \mathrm{AcOH}(0.5 \mathrm{~mL}), \mathrm{H}_{3} \mathrm{PO}_{4}(0.8 \mathrm{~mL}), 50{ }^{\circ} \mathrm{C}, 24 \mathrm{~h}$. ${ }^{b}$ Isolated yield based on $1 .{ }^{c}$ Selectfluor $(0.4 \mathrm{mmol})$ and $\mathrm{H}_{3} \mathrm{PO}_{4}(0.4 \mathrm{~mL})$ were used. ${ }^{d}$ Reaction time: $12 \mathrm{~h}$.

(eqn (1)). ${ }^{8 b, e}$ This addition-cyclization-fluorination sequence strongly supports the radical mechanism of carbofluorination.

On the basis of the above results and literature reports, ${ }^{7,8}$ a plausible mechanism is proposed as shown in Fig. 1. The interaction of $\mathrm{AgNO}_{3}$ with Selectfluor generates the $\mathrm{Ag}(\mathrm{III})-\mathrm{F}$ intermediate presumably via oxidative addition. The single electron transfer between acetic acid and $\mathrm{Ag}(\mathrm{III})-\mathrm{F}$ leads to the formation of $\alpha$-carbonyl radical $\mathbf{A}$ and $\mathrm{Ag}$ (II)-F. The electrophilic radical $\mathbf{A}$ then adds to an electron-rich alkene to give adduct radical B. Finally, the nucleophilic alkyl radical $\mathbf{B}$ abstracts a fluorine atom from Ag(II)-F to afford the carbofluorination product along with the regeneration of $\mathrm{Ag}(\mathrm{I})$. Thus, this reaction further expands the scope of radical fluorination. ${ }^{12}$ 


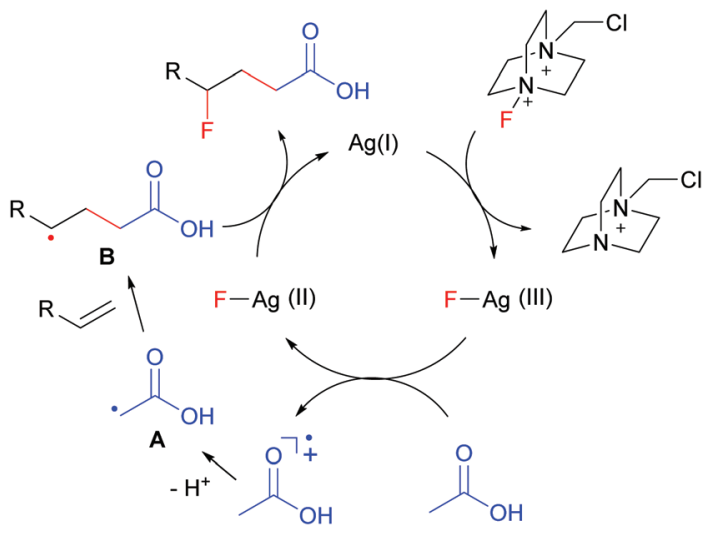

Fig. 1 Proposed mechanism of carbofluorination.

The above carbofluorination offers a convenient route to $\gamma$-fluorinated aliphatic carboxylic acids. The remarkable functional group compatibility also enables the carbofluorination products to be versatile building blocks for the synthesis of more complex fluorinated molecules. For example, upon treatment with $\mathrm{Cs}_{2} \mathrm{CO}_{3}$, the carbofluorination product $2 \mathbf{b}$ could be easily converted to $\gamma$-fluorocaprolactone 5 in $71 \%$ yield (eqn (2)). The reaction of analogous $\gamma$-fluoroacid 2e with $\mathrm{Cs}_{2} \mathrm{CO}_{3}$ in $\mathrm{DMF}$ did not offer the expected cyclization product $\gamma$-fluoroheptanolactone. Instead, the 16-membered cyclic dimer 6 was obtained exclusively in $80 \%$ yield as the mixture of two stereoisomers in a $1: 1$ ratio (eqn (3)). It is worth mentioning that the reaction of 6-bromohexanoic acid under almost identical conditions produced the corresponding cyclic dimer (similar to 6) rather than $5 .^{13}$ Thus, the formation of $\mathbf{5}$ from $2 \mathbf{b}$ might be attributed to the fluorine effect on substrate conformations.
3
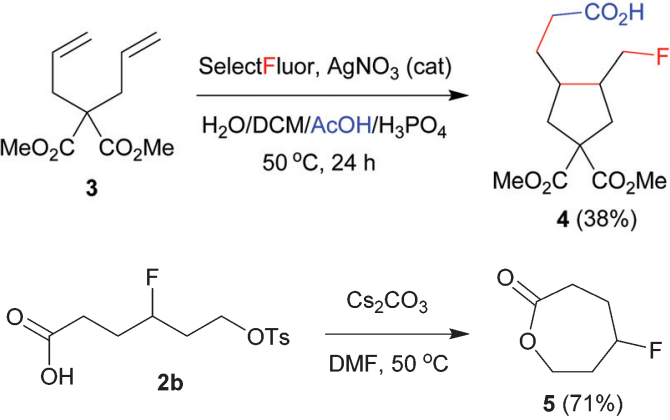<smiles>O=C(O)CCC(F)CCCBr</smiles>

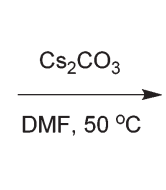

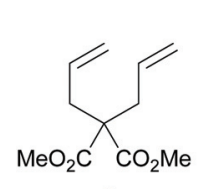

\section{Conclusion}

In summary, we have successfully developed the silvercatalyzed radical carbofluorination of unactivated alkenes with acetic acid and Selectfluor in aqueous solution. This threecomponent condensation proceeds under mild conditions, providing a convenient and efficient entry into various $\gamma$-fluorinated alkanoic acids with wide functional group compatibility.

\section{Experimental section}

Typical procedure for silver-catalyzed carbofluorination of unactivated alkenes with acetic acid

$N$-(Pent-4-en-1-yl)phthalimide (1a, $43.1 \mathrm{mg}, 0.2 \mathrm{mmol}), \mathrm{AgNO}_{3}$ (6.8 $\mathrm{mg}, 0.04 \mathrm{mmol}$ ) and Selectfluor (212.6 $\mathrm{mg}, 0.6 \mathrm{mmol}$ ) were placed in a Schlenk tube under a nitrogen atmosphere. Dichloromethane $(0.5 \mathrm{~mL})$, water $(1 \mathrm{~mL})$, acetic acid $(0.5 \mathrm{~mL})$ and $85 \%$ phosphoric acid $(0.8 \mathrm{~mL})$ were added successively at room temperature. The reaction mixture was then stirred at $50{ }^{\circ} \mathrm{C}$ for $24 \mathrm{~h}$. The resulting mixture was cooled down to room temperature and extracted with $\mathrm{CH}_{2} \mathrm{Cl}_{2}(3 \times 10 \mathrm{~mL})$. The organic phases were combined and dried over anhydrous $\mathrm{Na}_{2} \mathrm{SO}_{4}$. After the removal of solvent under reduced pressure, the crude product was purified by column chromatography on silica gel with dichloromethane/methanol $(60: 1, \mathrm{v}: \mathrm{v})$ as the eluent to give the pure product $\mathbf{2 a}$ as a white solid. Mp: 86-88 ${ }^{\circ}$ C. Yield: $49.1 \mathrm{mg}$ (84\%). ${ }^{1} \mathrm{H}$ NMR (400 $\mathrm{MHz}, \mathrm{CDCl}_{3}$ ): $\delta$ 7.83-7.85 (m, 2H), 7.70-7.72 (m, 2H), 4.48-4.64 (m, 1H), 3.69-376 (m, 2H), 2.46-2.57 (m, 2H), 1.55-1.96 (m, 6H); ${ }^{13} \mathrm{C}$ NMR (100 MHz, $\mathrm{CDCl}_{3}$ ): $\delta 178.6,168.4,133.9,132.0,123.2$, $92.4(\mathrm{~d}, J=169.0 \mathrm{~Hz}), 37.5,32.2(\mathrm{~d}, J=20.6 \mathrm{~Hz}), 29.9(\mathrm{~d}, J=$ $21.0 \mathrm{~Hz}$ ), 29.5 (d, $J=4.3 \mathrm{~Hz}), 24.3$ (d, $J=3.9 \mathrm{~Hz}) ;{ }^{19} \mathrm{~F}$ NMR $\left(282 \mathrm{MHz}, \mathrm{CDCl}_{3}\right): \delta-183.8(\mathrm{~m}, 1 \mathrm{~F})$; IR $(\mathrm{KBr}): \nu\left(\mathrm{cm}^{-1}\right) 2942$, 1772, 1719, 1713, 1707, 1440, 1400, 1367, 1051, 721; ESI-MS: $(\mathrm{m} / \mathrm{z}) 316.1(\mathrm{M}+\mathrm{Na})$; HRMS calcd for $\mathrm{C}_{15} \mathrm{H}_{16} \mathrm{FNNaO}_{4}(\mathrm{M}+\mathrm{Na})$ : 316.0956, found 316.0966 .

\section{Acknowledgements}

This project was supported by the National Basic Research Program of China (973 Program) (Grant 2015CB931900), by the National Natural Science Foundation of China (Grants 21272259, 21290180, 21421002, 21472220, 21502210, 21532008, 21602239, and 21361140377), and by the Strategic Priority Research Program of the Chinese Academy of Sciences (Grant XDB20020000).

\section{Notes and references}

1 (a) K. Muller, C. Faeh and F. Diederich, Science, 2007, 317, 1881; (b) S. Purser, P. R. Moore, S. Swallow and V. Gouverneur, Chem. Soc. Rev., 2008, 37, 320; (c) P. Jeschke, ChemBioChem, 2004, 5, 570.

2 (a) T. Liang, C. N. Neumann and T. Ritter, Angew. Chem., Int. Ed., 2013, 52, 8214; (b) X. Mu and G. Liu, Org. Chem. Front., 2014, 1, 430; (c) J. Ma and S. Li, Org. Chem. Front., 2014, 1, 712; (d) A. J. Cresswell, S. G. Davies, P. M. Roberts 
and J. E. Thomson, Chem. Rev., 2015, 115, 566; (e) M. G. Campbell and T. Ritter, Chem. Rev., 2015, 115, 612; (f) C. Ni, M. Hu and J. Hu, Chem. Rev., 2015, 115, 765; (g) X. Yang, T. Wu, R. J. Phipps and F. D. Toste, Chem. Rev., 2015, 115, 826; (h) P. A. Champagne, J. Desroches, J.-D. Hamel, M. Vandamme and J.-F. Paquin, Chem. Rev., 2015, 115, 9073.

3 (a) K. Lucet-Levannier, J.-P. Lellouche, C. Mioskowski, F. Schneider and C. Cassagne, Tetrahedron Lett., 1996, 37, 2007; (b) T. Verbrugghen, P. Cos, L. Maes and S. V. Calenbergh, J. Med. Chem., 2010, 53, 5342.

4 (a) N. J. M. Birdsall, Tetrahedron Lett., 1971, 12, 2675; (b) J.-D. Charrier, D. S. Hadfield, P. B. Hitchcock and D. W. Young, Org. Biomol. Chem., 2004, 2, 797; (c) J. Guimond-Tremblay, M.-C. Gagnon, J.-A. PineaultMaltais, V. Turcotte, M. Auger and J.-F. Paquin, Org. Biomol. Chem., 2012, 10, 1145.

5 R. J. M. Goss and H. Hong, Chem. Commun., 2005, 3983.

6 (a) R. E. Banks, S. N. Mohialdin-Khaffaf, G. S. Lal, I. Sharif and R. G. Syvret, J. Chem. Soc., Chem. Commun., 1992, 595; (b) R. P. Singh and J. M. Shreeve, Acc. Chem. Res., 2004, 37, 31; (c) P. T. Nyffeler, S. G. Durón, M. D. Burkart, S. P. Vincent and C.-H. Wong, Angew. Chem., Int. Ed., 2005, 44, 192.

7 F. Yin, Z. Wang, Z. Li and C. Li, J. Am. Chem. Soc., 2012, 134, 10401.
8 (a) Z. Li, L. Song and C. Li, J. Am. Chem. Soc., 2013, 135, 4640; (b) C. Zhang, Z. Li, L. Zhu, L. Yu, Z. Wang and C. Li, J. Am. Chem. Soc., 2013, 135, 14082; (c) Z. Li, Z. Wang, L. Zhu, X. Tan and C. Li, J. Am. Chem. Soc., 2014, 136, 16439; (d) L. Zhu, H. Chen, Z. Wang and C. Li, Org. Chem. Front., 2014, 1, 1299; (e) Z. Li, C. Zhang, L. Zhu, C. Liu and C. Li, Org. Chem. Front., 2014, 1, 100.

9 (a) J. B. Bush Jr. and H. Finkbeiner, J. Am. Chem. Soc., 1968, 90, 5903; (b) B. B. Snider, Chem. Rev., 1996, 96, 339.

10 (a) A. D. Dilman, P. A. Belyakov, M. I. Struchkova, D. E. Arkhipov, A. A. Korlyukov and V. A. Tartakovsky, J. Org. Chem., 2010, 75, 5367; (b) E. P. A. Talbot, T. A. Fernandes, J. M. McKenna and F. D. Toste, J. Am. Chem. Soc., 2014, 136, 4101; (c) H. Wang, L.-N. Guo and X.-H. Duan, Chem. Commun., 2014, 50, 7382; (d) S. Kindt and M. R. Heinrich, Chem. - Eur. J., 2014, 20, 15344; (e) R. Guo, H. Yang and P. Tang, Chem. Commun., 2015, 51, 8829.

11 For an example of 1,2-oxyfluorination of alkenes, see: Y.-Y. Liu, J. Yang, R.-J. Song and J.-H. Li, Adv. Synth. Catal., 2014, 356, 2913.

12 M. P. Sibi and Y. Landais, Angew. Chem., Int. Ed., 2013, 52, 3570 .

13 W. H. Kruizinga and R. M. Kellogg, J. Am. Chem. Soc., 1981, 103, 5183. 